\title{
Näkökulma aikuiskoulutuksen kustannuksiin
}

Aikuiskasvatuksen numerossa 4/84 oli mielenkiintoinen artikkeli vapaan sivistystyön kustannuksista ${ }^{1)}$. Näkökulman laajentamiseksi ammatillisen aikuiskoulutuksen suuntaan olen oheen kerännyt eräitä tunnuslukuja käyttömenojen määrästä opetustuntia kohden.

Koulukustannusten ja suoritteiden seurantajärjestelmän piiriin kuuluvat kouluhallituksen ja ammattikasvatushallituksen alaiset kunnalliset, yksityiset ja valtion oppilaitokset. Vuosittan toistuva oppilaitosten taloutta ja suoritteita koskevien tietojen keruu oppilaitoksilta, tietojen käsittely ja raportointi sekä käyttö kouluhallinnon eri tarkoituksiin muodostavat kokonaisuutena valtakunnallisen koulukustannusten ja -suoritteiden seurantajärjestelmän.

Oheinen taulukko perustuu tämän ns. koulukustannusrekisterin tietosisältöön. Huomionarvoista on mm. se, että keskimääräiset käyttömenot opetustuntia kohden eri oppilaitostyypeissä vaihtelevat melkoisesti.

Opetustuntia kohden keskimäärin halvinta toteutunut aikuiskoulutus oli hoitoalan oppilaitoksissa (110 mk). Selvästi kalleinta koulutus opetustuntia kohden oli kansanopistoissa (428 mk).

Vertailun vuoksi mainittakoon, että kaikki käyttökustannukset muussa kuin kurssitoiminnassa opetustuntia kohden ovat kauppaoppilaitoksissa $146 \mathrm{mk}$, yleisissä ammattikouluissa $162 \mathrm{mk}$, teknillisissä oppilaitoksissa $222 \mathrm{mk}$ ja hoitoalan oppilaitoksissa $186 \mathrm{mk}$.

Varsinaisen johtopäätösten teon haluan jättää lukijoiden tehtäväksi. Seuraavassa kuitenkin eräitä lisätietoja, jotka auttavat hahmottamaan tilannetta.

\footnotetext{
1) Pentti Yrjölä: Aikuiskasvatus valtion budjetissa ja koulukustannukset vapaassa sivistystyössä. Aikuiskasvatus 4/1984.
}

Kansanopistoilla on melko paljon valtionapuun oikeuttamattomia menoja. Valtionapuun oikeuttavia käyttökustannuksia niillä oli vuonna 1983 opetustuntia kohden 317 mk (kaikki käyttömenot $428 \mathrm{mk}$ ).

Opintokeskusten menot pitävät sisällään kurssitoimintaan liittyvät menot. Melko suuret yleismenot eivät näy toimintamuodoittaisissa erittelyissä.

Ammatillisten kurssikeskusten ja osittain muidenkin ammatillisten oppilaitosten käyttömenot pitävät sisällään oppilaille työllisyyskoulutuksessa maksettavat avustukset. Ilman näitä keskimääräiset käyttömenot opetustuntia kohden ovat ammatillisissa kurssikeskuksissa $163 \mathrm{mk}$ (kaikki käyttömenot $242 \mathrm{mk}$ ) ja esimerkiksi teknillisissä oppilaitoksissa $354 \mathrm{mk}$ (kaikki käyttömenot $392 \mathrm{mk}$ ) sekä kauppaoppilaitoksissa $126 \mathrm{mk}$ (kaikki käyttömenot 243 $\mathrm{mk}$ ).

Teollisuuden ammattioppilaitosten käyttömenot pitävät sisällään oppilaspalkkoja. Ilman näitä keskimääräiset käyttömenot opetustuntia kohden ovat $316 \mathrm{mk}$ (kaikki käyttömenot $349 \mathrm{mk}$ ).

On muistettava, että eri oppilaitostyypeissä opetusryhmissä on erilainen määrä oppilaita. Tästä syystä keskimääräinen yhden henkilön koulutus yhden opetustunnin aikana ei jakaudu täysin samalla tavalla kuin oheisen taulukon luvut. Osittain opetusryhmien kokoeroissa on kyse todellisista opetustilanteiden vaatimuksista. Osittain on kyse perinteestä ja erilaisten "vaikuttajaryhmien" toiminnasta.

Lisäksi on muistettava, että valtio tukee eri koulutusmuotoja eri tavalla. Valtion osuus hyväksyttävistä käyttömenoista on erilainen, ja hyväksyttävien käyttömenojen osuus kaikista käyttömenoista on erilainen eri koulutusmuodoissa. Esimerkiksi teollisuuden ammattikouluissa ${ }^{1)}$ valtionosuus on noin $24 \%$ ja ammatil- 
lisissa kurssikeskuksissa ${ }^{1)}$ noin $85 \%$ kaikista käyttömenoista. Vastaavasti kansalais- ja työväenopistojen valtionosuus on $68 \%$, kansanopistojen $54 \%$ ja opintokeskusten kurssitoiminnasta ${ }^{2)} 57 \%$ kaikista käyttömenoista. Siten valtio tukee yhtä opetustuntia seuraavasti:

\begin{tabular}{|c|c|}
\hline & $\begin{array}{l}\text { Tuki } \\
\text { mk/opetus- } \\
\text { tunti }\end{array}$ \\
\hline Teollisuuden ammattikoulut & 83 \\
\hline Ammatilliset kurssikeskukset & $207^{3)}$ \\
\hline Kansalais- ja työväenopistot & 109 \\
\hline Kansanopistot & 230 \\
\hline $\begin{array}{l}\text { Opintokeskusten kurssi- } \\
\text { toiminta }\end{array}$ & $111^{2)}$ \\
\hline
\end{tabular}

Koulukustannusten määrään eri oppilaitostyypeissä vaikuttaa opetuksen sisältö. Tästä syystä on luonnollista, että esim. uusimman teknologisen tiedon opettamisessa keskimäärin pisimmällä olevilla teollisuuden ammattikouluilla ovat kustannukset keskimääräistä suuremmat.
Korkeakoulutasoisesta aikuiskoulutuksesta ei ole saatavissa tietoa vuodelta 1983. Vuonna 1982 avoimen korkeakouluopetuksen käyttömenot olivat $924000 \mathrm{mk}$ ja opetustunteja oli 7247 , joten käyttömenot opetustuntia kohden olivat $128 \mathrm{mk}$. Täydennyskoulutuksen käyttömenot olivat $11705000 \mathrm{mk}$ ja opetustunteja oli 61705 , joten käyttömenot opetustuntia kohden olivat $190 \mathrm{mk}$.

Edelläolevilla kustannusvertailuilla en mitenkään ole halunnut asettaa eri aikuiskoulutusmuotoja vastakkain riitelemään samasta rahasta. Niillä kaikilla on oma tärkeä tehtäväkenttänsä. Olen halunnut ainoastaan osoittaa, että monet hyvinkin sitkeästi elävät käsitykset eri koulutusmuotojen kalleudesta ja halpuudesta eivät ole niin yksiselitteisiä. Kustannuksia voidaan tarkastella monella tavalla, ja tarkastelutavasta riippuen voidaan esittää erilaisia väitteitä. Nähdäkseni kuitenkin opetustuntien määrä kertoo melko hyvin toiminnan laajuudesta. Oppilasmäärät ja oppilaspäivien lukumäärät eivät samalla tavoin ota huomioon eri alojen vaatimuksia.

Taulukko 1. Opetustuntien hinta eräissä aikuiskoulutusmuodoissa vuonna 1983

\begin{tabular}{lrrr}
\hline Oppilaitostyyppi & Opetustunteja & $\begin{array}{c}\text { Käyttömenoja } \\
\text { mk }\end{array}$ & $\begin{array}{r}\text { Käyttömenoja } \\
\text { opetustuntia } \\
\text { kohden }\end{array}$ \\
\hline Kansalais- ja työväenopistot & 1864373 & 301751000 & 162 \\
Kansanopistot & 584846 & 250559000 & 428 \\
Opintokeskusten kurssitoiminta & 136031 & 26492000 & 195 \\
Ammatilliset kurssikeskukset & 3411834 & 827229000 & 242 \\
Teollisuuden ammattikoulut & 268194 & 93491000 & 349 \\
Kurssitoiminta seuraavissa & & & \\
oppilaitostyypeissä: & 27553 & 4808000 & 175 \\
- Maatalousoppilaitokset & 44030 & 16012000 & 364 \\
- Metsäoppilaitokset & 40841 & 6627000 & 162 \\
- Yleiset ammattikoulut & 30498 & 11948000 & 392 \\
- Teknilliset oppilaitokset & 141324 & 34409000 & 243 \\
- Kauppaoppilaitokset & 10465 & 1214000 & 116 \\
- Käsi- ja taideteollisuusoppilaitokset & 20804 & 2295000 & 110 \\
- Hoitoalan oppilaitokset & 7501 & 932000 & 124 \\
- Kotitalousoppilaitokset & & & \\
$\quad$ oppelli- ja ravintola-alan & 7027 & 2262000 & 322 \\
\hline Peruskoulut & 34183000 & 6620000000 & 194 \\
Lukiot & 5355000 & 1130000000 & 211
\end{tabular}

\footnotetext{
1) Sisältää avustukset opiskelijoille.

2) Ei sisällä opintokeskusten yleismenoja.

3) Arviolta 1/3 oppilasavustuksia.
} 